\title{
SERUM PHOSPHATASE IN THE LYMPHOMATOID DISEASES
}

\author{
BY H. Q. WOODARD AND LLOYD F. CRAVER \\ (From the Memorial Hospital, New York City)
}

(Received for publication July 5, 1939)

Lesions of the skeletal system caused by the lymphomatoid diseases probably occur more often than is indicated by any published reports. We believe that the true incidence of gross changes in the bones is much higher in Hodgkin's disease than is generally known. We strongly suspect that under modern conditions of radiation therapy of Hodgkin's disease, resulting in 17 to 34 per cent of survivals for five years or longer, a complete roentgenographic study of cases at various stages would reveal perhaps as much as a 50 per cent incidence of gross bone changes. Therefore, the question of bone lesions is an important one in relation to the treatment of Hodgkin's disease and also, though apparently to a less extent, in lymphosarcoma and the leukemias.

In recent years the diagnosis and management of various types of bone tumors, primary and metastatic, and of such disorders as Paget's disease and hyperparathyroidism, have been materially aided by studies of serum phosphatase, phosphorus and calcium.

In view of the foregoing premises, it seemed advisable to undertake a study of these blood constituents in the lymphomatoid diseases. The two objectives of this study were (1) to determine the relation between demonstrable bone lesions and the chemical findings, and (2) to ascertain whether the chemical findings might furnish some indication of the existence of bone lesions before they could be demonstrated roentgenographically. As the study progressed, a third objective arose: to determine whether in the lymphomatoid diseases some feature other than bone lesions could account for high serum phosphatase values, and especially whether the granulomatous tissue itself could cause an elevation of the phosphatase.

It will be well at this point to review what is known of the relation of serum phosphatase to bone disease. Many tissues contain enzymes which will hydrolyze organic phosphorus compounds to give free: phosphoric acid. Some of these phosphatases are most active in an alkaline medium, others in an acid medium. Thus, the phosphatases of bone (1), bile (2), and white blood cells (3) are alkaline phosphatases, while those of the liver (4), kidney (4), prostate (5), and red blood cells (6) are acid phosphatases. In the course of the present work it was found that normal lymph nodes, Hodgkin's nodes, and lymphosarcoma tissue contain both acid and alkaline phosphatases in small amounts. Most of the alkaline phosphatase of the serum comes from the bones, and the only non-osseous disease which is known to cause an elevation of the alkaline phosphatase of the serum is jaundice of obstructive or hepatic origin. If jaundice is excluded, an elevation of the alkaline phosphatase of the serum is strong indication of the presence of bone disease. As comparatively little work has been done on acid phosphatase, the term " phosphatase" usually indicates the alkaline enzyme and will be so used in this paper.

Serum phosphatase is high whenever the body is forming bone or attempting to do so. Thus it is high in normal children because the bones are growing. It is very high in rickets, because the bones are attempting to grow but are prevented from doing so because of inadequate supplies of calcium or phosphorus. It is high in hyperparathyroidism, and the excess production of phosphatase probably indicates a defense reaction on the part of the bones against the osteolytic process which is stimulated by parathyroid hormone (7).

Serum phosphatase usually is high in cases with primary or metastatic bone tumors of osteoplastic type, and is normal or slightly raised in the presence of primary or metastatic bone tumors of osteolytic type. The excess phosphatase which appears in the serum of patients with primary bone tumors is produced the tumor tissue as part of its metabolism, and can readily be identified in extracts of the tissue $(8,9)$. The excess phosphatase in the serum of patients with carcinoma metastatic to bone probably is produced as 
part of a defense reaction set up in adjacent normal bone against invasion by tumor tissue.

\section{METHODS}

Serum phosphatase was determined by a modification of the Bodansky method which has been described in detail elsewhere (10). Estimation of the icteric index is a part of this procedure. Acid serum phosphatase was determined at $\mathrm{pH} 6.4$ (11). The method was the same as for alkaline phosphatase except that the veronal buffer was omitted from the substrate. By the method used, normal values for alkaline serum phosphatase are 1.7 to 5.0 units, values above 4.5 units being rare and the average being 3.0 units. The acid serum phosphatase seldom exceeds 5 per cent of the alkaline phosphatase in normals or in patients with primary bone disease, but is markedly elevated in cases of carcinoma of the prostate metastatic to bone. Tissue phosphatase was determined by a modification (9) of the method of Franseen. Sodium beta glycerophosphate was used as substrate throughout. As most of the patients were seen in the out-patient department, the blood samples were usually obtained in the non-fasting condition.

Three types of cases were chosen for examination:

$A$. Patients without evidence of bone disease.

$B$. Patients with symptoms suggestive of bone involvement but with negative films. In some of these patients the symptoms were probably, but not certainly, due to coexistent arthritis.

C. Patients with bone lesions demonstrable roentgenographically.

It should be emphasized that these patients were selected with a view to possible bone disease. Only enough cases without bone symptoms were examined to give an adequate control group. An unselected series of patients from the same clinic would include a much larger percentage without symptoms referable to the bones.

All the patients reported were adults. A few children were also examined but are not included here, since it is very difficult to evaluate serum phosphatase findings in growing individuals, owing to the wide range of normal variation.

\section{RESULTS}

Results for serum phosphatase are summarized in Table I. Values above 5.0 units per $100 \mathrm{cc}$. are considered abnormal. Serial observations were made on many of the patients over periods ranging from a few months to nearly two years. During this time some patients who had at first no evidence of bone disease developed pain in the bones. Others who had symptoms suggestive of bone involvement without roentgenographic changes later showed frank lesions. Whenever such a change in the status of the patient with
TABLE I

Summary of the serum phosphatase readings of 115 patients with lymphomatoid disease

\begin{tabular}{c|c|c|c|c|c|c}
\hline \hline Diagnosis & $\begin{array}{c}\text { Cases without } \\
\text { bone symptoms }\end{array}$ & $\begin{array}{c}\text { Cases with } \\
\text { bone symptoms } \\
\text { but with } \\
\text { normal x-rays }\end{array}$ & $\begin{array}{c}\text { Cases with } \\
\text { bone lesions } \\
\text { shown roent- } \\
\text { genographically }\end{array}$ \\
\cline { 2 - 5 } & $\begin{array}{c}\text { Total } \\
\text { num- } \\
\text { ber }\end{array}$ & $\begin{array}{c}\text { Number } \\
\text { with } \\
\text { wevated } \\
\text { P-ase }\end{array}$ & $\begin{array}{c}\text { Total } \\
\text { num- } \\
\text { ber }\end{array}$ & $\begin{array}{c}\text { Number } \\
\text { with } \\
\text { elevated } \\
\text { P-ase }\end{array}$ & $\begin{array}{c}\text { Total } \\
\text { num- } \\
\text { ber }\end{array}$ & $\begin{array}{c}\text { Number } \\
\text { with } \\
\text { elevated } \\
\text { P-ase }\end{array}$ \\
\hline $\begin{array}{c}\text { Hodgkin's } \\
\text { disease........ }\end{array}$ & 11 & 3 & 36 & 21 & 19 & 14 \\
\hline Lymphosarcoma. & 13 & 4 & 8 & 5 & 9 & 3 \\
\hline The leukemias... & 15 & 4 & 11 & 1 & 3 & 1 \\
\hline Miscellaneous.... & 1 & 1 & 4 & 3 & 3 & 2 \\
\hline Total............ & 40 & 12 or & 59 & $\begin{array}{c}30 \text { or } \\
51 \text { per } \\
\text { cent }\end{array}$ & 34 & $\begin{array}{c}20 \text { or } \\
59 \text { per } \\
\text { cent }\end{array}$ \\
\hline
\end{tabular}

respect to evidence of bone disease occurred, another record was made in the appropriate column. The table therefore contains 134 entries relating to 115 patients.

Determinations of total serum calcium and of serum inorganic phosphorus were made on all cases but are not recorded in the table as no striking deviations from normal were observed. A slight elevation of serum inorganic phosphorus was found in about a third of the Hodgkin's cases and may possibly be of significance. In the leukemias the total serum calcium averaged a little low, but this was not related to the presence of a hemorrhagic tendency and was probably due to the poor nutrition of many of these patients.

The section of the table entitled "Miscellaneous" includes 3 cases with a tendency both to polycythemia and leukemia, and 1 each of giant follicular lymphoma, non-specific lymphadenitis, mycosis fungoides, probably aleukemic lymphatic leukemia, and aleukemic myeloid leukosarcoma. In most of the patients with leukemia and polycythemia, the diagnosis was established by blood examination alone. In all the others except 3 the diagnosis was verified by biopsy. In the group of 26 cases of leukemia, 19 were of the lymphatic type, 4 of the myelogenous, and 3 of the pseudoleukemic.

It is evident at once from inspection of the table that an elevation of serum phosphatase is very common in the lymphomatoid diseases. It 
occurred in over half the cases with known bone involvement or with symptoms suggestive of bone involvement, and also in more than a quarter of the cases in which there was no reason to suspect that the bones were affected. When the different diagnostic groups are examined separately, it is seen that for the 66 determinations on 53 cases of Hodgkin's disease the relation between elevation in serum phosphatase and evidence of bone disease is very close. The actual values could not be presented in the table, but it may be stated here that in Hodgkin's cases with severe bone symptoms the elevation of serum phosphatase was often marked, the readings being above 15 units in 9 patients and above 35 units in 2 . The histories of some of these patients will be examined in detail later.

The miscellaneous group is too small to be of much significance, but the relation of changes in serum phosphatase to bone symptoms is fairly close.

The patients with lymphosarcoma present many puzzling features, as an elevation of serum phosphatase is encountered as often in the patients without evidence of bone involvement as in those with demonstrable lesions. In the group of patients with leukemia, well-defined bone lesions were rare. Elevations of serum phosphatase were small, only one value exceeding 6.5 units being found. They occurred infrequently and bore little relation to the presence of symptoms referable to the bones.

Because of the lack of correlation between the presence of elevated serum phosphatase values and evidence of bone disease in lymphosarcoma and the leukemias, the question presents itself whether the excess phosphatase in the serum of many of these patients comes from the bones or from some other tissue. The latter is an important possibility, as many patients with lymphomatoid disease have large masses of abnormal tissue and radical disturbances of the vital metabolic processes.

An increase in metabolic rate is common in these patients. It is not associated with symptoms of hyperthyroidism and its exact cause is obscure. Little evidence is available at present regarding the effect of metabolic rate on serum phosphatase, although the phosphatase appears to be somewhat elevated in hyperthyroidism (12). We have not determined the basal metabolic rate on the cases presented here, but we observe that gross abnormalities in serum phosphatase are encountered least often in the leukemias where an accelerated metabolism is most common. In several patients with Hodgkin's disease, there was no relation between the serum phosphatase readings and the presence of fever. We feel, therefore, that while an increase in the metabolic rate may explain why many patients with leukemia have serum phosphatase values in the upper normal range, it does not account for the markedly elevated phosphatase readings so often found in Hodgkin's disease.

The two most probable non-osseous sources of the excess phosphatase in the serum are the bile and the lymphomatoid tissue. None of the patients reported here had an elevated icteric index, so it is unlikely that there were significant amounts of bile phosphatase in the serum. While recent work (13) has shown that the serum phosphatase may remain elevated for a time after the icteric index has returned to normal following an attack of jaundice, further evidence has just been obtained in the course of an uncompleted investigation by one of us (H. Q. W.) which indicates that moderate liver dysfunction without jaundice does not produce significant changes in the serum phosphatase. We feel, therefore, that liver disease is not an important factor in our phosphatase findings, but cannot be definitely excluded in all cases.

Since it was found that the amounts of both acid and alkaline phosphatase in the lymphomatoid tissue were small, it does not seem likely that enzyme from this tissue was responsible for the high values found for alkaline serum phosphatase. Additional evidence on this point was obtained from determination of the acid phosphatase of the serum. This was done on 29 cases with an elevated alkaline phosphatase and 25 cases with a normal alkaline phosphatase. No abnormalities in the acid phosphatase were found. It is improbable that leakage of alkaline phosphatase to the serum would take place without corresponding leakage of acid phosphatase.

Although the above evidence does not favor a non-osseous origin for elevations of the serum 
phosphatase, an attempt was also made to use statistical methods to discover whether there was a correlation between changes in phosphatase and the presence of extensive adenopathy or of enlargement of the liver or spleen. This method is not entirely satisfactory because lesions of liver, spleen, bones, and glandular systems cannot be considered as independent variables, and are likely to occur simultaneously late in the disease. Nevertheless, significant exceptions to this are often found, and the statistical study was therefore made. It showed that, for Hodgkin's disease, the only positive correlation was that between serum phosphatase and evidence of bone disease. The series of cases of lymphosarcomas and the leukemias were rather small to be significant but suggested that disease of the liver or spleen might be a factor in raising the serum phosphatase.

Since the white blood cells contain alkaline phosphatase, it is theoretically possible for enzyme from this source to raise the serum level. However, it was apparent at once that this was not an important practical factor. An elevated serum phosphatase was infrequent in the leukemias, and bore no relation to the white count when it did occur.

Although previous work has failed to show any evidence that radiation therapy has a direct effect on the serum phosphatase (14), the possibility of such an effect must be considered here. In the leukemias, particularly, the destruction of the white blood cells might result in the liberation of significant amounts of alkaline phosphatase into the serum, even though the intact cells do not affect the serum level. Many of our patients were under almost continuous treatment, so that it was not possible to obtain blood samples more than a few weeks after the last irradiation. Adequate observations on the effect of a single course of treatment were obtained on 4 cases, however, and are summarized below.

In the last case, irradiation resulted in a drop in the total white count from 92,400 to 17,200 . The variations in phosphatase observed are within normal limits. This confirms our previous observations.

Irradiation of tissues other than the bones does not appear, therefore, to have a significant effect on the serum phosphatase in these patients.

\begin{tabular}{|c|c|c|c|}
\hline Diagnosis & $\begin{array}{l}\text { Phos- } \\
\text { phatase } \\
\text { before } \\
\text { treat- } \\
\text { ment }\end{array}$ & $\begin{array}{l}\text { Phos- } \\
\text { phatase } \\
\text { after } \\
\text { treat- } \\
\text { ment }\end{array}$ & Area treated \\
\hline & $\begin{array}{c}\text { Bodansky } \\
\text { units }\end{array}$ & $\begin{array}{c}\text { Bodansky } \\
\text { units }\end{array}$ & \\
\hline ease............ & 3.3 & 2.2 & $\begin{array}{l}\text { Supraclavicular and } \\
\text { mediastinum }\end{array}$ \\
\hline $\begin{array}{l}\text { Hodgkin's dis- } \\
\text { ease........... } \\
\text { Lymphosarcoma }\end{array}$ & $\begin{array}{l}4.3 \\
4.8\end{array}$ & $\begin{array}{l}4.7 \\
3.6\end{array}$ & $\begin{array}{l}\text { Chest } \\
\text { Abdomen }\end{array}$ \\
\hline $\begin{array}{l}\text { Lymphatic } \\
\text { leukemia ....... }\end{array}$ & 4.8 & 4.6 & Neck and groins \\
\hline
\end{tabular}

From this discussion of the possible origins of serum phosphatase, it appears that in Hodgkin's disease all the evidence is in favor of an osseous origin for the excess phosphatase in the serum. This may also be true in lymphosarcoma and the leukemias, but in these diseases other possible sources of serum phosphatase have not been excluded.

\section{PROTOCOLS}

Some of the material summarized in the table will now be examined in more detail. In the group of 11 Hodgkin's patients who had no symptoms referable to the bones at the time of the first serum phosphatase determination, the majority had normal or high normal phosphatase readings.

The subsequent course of Case 12, who had an elevation of serum phosphatase which was unexplained at first, is of especial interest. This patient, a female aged 42 , had been under treatment for proved Hodgkin's disease for two years. Her first phosphatase reading was slightly elevated at 5.9 units. At this time she was in good health but had a large supraclavicular mass. During the next three months she received two cycles of roentgen irradiation to the supraclavicular regions and mediastinum. At the close of treatment the adenopathy had regressed somewhat and the serum phosphatase was 5.7 units. Four months later she developed marked involvement of the head of the femur. She stated at this time that she had noted minor discomfort in this region for a period of one year, but she considered it too trivial to mention. The area was irradiated, but after completion of treatment the serum phosphatase was 9.1 units, and rose to $\mathbf{1 1 . 7}$ units during the next four months. At this time her general condition had deteriorated, there was massive adenopathy adherent to, and probably involving, the sternum, and a film showed that the femoral lesion was not healing. It is likely that in this case the bones were invaded early, but that it was not until the disease became very active that the bone disturbance was sufficient to cause serious symptoms. 
In the group of cases of Hodgkin's disease with symptoms referable to bones, an elevation of the serum phosphatase was frequently encountered. In 3 of the patients who had serum phosphatase values within normal limits, the symptoms were probably due to co-existent arthritis.

In Case 22 (M. R.), a male aged 39 with a seven-year history of Hodgkin's disease had serum phosphatase values which remained approximately constant at the somewhat elevated level between 6.6 and 8.2 units for a period of one year. Eighteen months after the first determination an exacerbation of bone symptoms was associated with a rise of phosphatase to 12.5 units. During this time the general condition was poor and the spleen was somewhat enlarged but there was little or no palpable adenopathy. The patient complained constantly of pain in the shoulder, lumbar spine, and pelvis, but repeated roentgenograms of these areas failed to show frank lesions, although on several occasions a questionable alteration of density was noted. During the period of observation the patient received five cycles of roentgen ray treatment to the spleen and the suspected bones. It is difficult to escape the conclusion that in this patient Hodgkin's disease was present extensively in and about the bones and contributed to the marked impairment of the general health in the absence of external adenopathy. It was, however, controlled sufficiently by irradiation therapy to prevent the development of demonstrable lesions.

In Case 28 (J. H.), a male aged 31 with a four-year history of Hodgkin's disease had some pain and tenderness in the spine, but films were negative except for questionable wedging of the fifth lumbar vertebra. He was observed for nine months during which period his serum phosphatase rose irregularly from 8.4 units to the high value of 30.5 units. At different times he showed rather extensive axillary, mediastinal and epigastric masses which were treated by three roentgen ray cycles. His general condition deteriorated and he died one month after the last observation. It is noteworthy that, except for the irradiation of the sternum incidental to the mediastinal therapy, this patient received little roentgen ray treatment to the bones which are commonly involved in Hodgkin's disease. It is probable that he had extensive but nearly symptomless bone disease which progressed in parallel with disease elsewhere in the body.

In Case 31 (F. D.), a male aged 32 with a two-year history of Hodgkin's disease complained of bone pain, but films of the lumbar spine, pelvis, and knees were essentially negative. His first serum phosphatase determination showed a moderately elevated value of 7.6 units. At this time he was in fair condition with no palpable adenopathy, but he soon developed evidence of disease requiring a cycle of roentgen irradiation to the abdomen and treatment in the Heublein total irradiation unit. This failed to control the process so that, three months after the first phosphatase determination, he developed marked adenopathy and a temperature of 101 . His serum phosphatase at this time was approximately unchanged at 6.9 units. He received another course of Heublein therapy with little improvement, and in three months his serum phosphatase had risen to 12.0 units. Six weeks later a film of the dorsal spine showed definite sclerotic changes. After another treatment in the Heublein unit there was marked improvement in the adenopathy and general health, but the serum phosphatase rose to $\mathbf{1 7 . 4}$ units. There was coincident increase in back pain and films showed sclerosis of the dorsal vertebrae and decalcification of the pelvis. Roentgen irradiation of the dorsal spine resulted in relief of pain, but the serum phosphatase remained unchanged at $\mathbf{1 7 . 7}$ units, probably owing to the pelvic lesions. Seven months later the general condition was poor and the bone symptoms had become severe, with a corresponding rise of the serum phosphatase to 36.4 units. In this case, the serum phosphatase paralleled the evidence of bone involvement closely over a period of twenty-one months, and showed no relation to the wide fluctuations in adenopathy.

In the group of Hodgkin's cases with bone lesions demonstrable roentgenographically, there is no close relation between the degree of elevation of serum phosphatase and the amount of new bone formed. Thus, 2 patients with long-standing and fairly extensive osteoplastic lesions had serum phosphatase values which ranged between 2.6 and 4.8 units, while in 3 other patients who showed osteolysis, the phosphatase was from 7.5 to 15.7 units. It may be significant that 1 of these eventually developed some osteoplasia. This is in contrast to the usual findings in carcinoma metastatic to bone where the serum phosphatase usually corresponds closely to the degree of osteoplasia.

In Case 38 (A. M.), a female aged 46 with a threeyear history of Hodgkin's disease was observed for eighteen months. During this time she had little adenopathy but her general condition was only fair and disease activity showed itself at intervals in the form of herpes, dermatitis and recurrent attacks of gastro-intestinal disturbance and fever. These were treated by cautious roentgen therapy and supportive measures. Nine months prior to the first phosphatase determination there had been a small osteolytic lesion of the third lumbar vertebra and symptoms suggestive of pelvic disease without roentgenographic changes. These became symptomless, but the serum phosphatase at first examination was found to be definitely elevated at $\mathbf{7 . 0}$ units, and rose steadily to 12.6 units over a period of eleven months. This prompted a re-examination of the pelvis, and a large lesion of the left ilium was discovered. The region soon began to be painful and was irradiated with relief of symptoms. The serum phosphatase continued to rise to 22.0 units, however, and we anticipate that there will soon be evidence of disease in other bones. 
In view of the uncertainty existing as to the significance of serum phosphatase changes in lymphosarcoma and the leukemias, the histories of patients with these diseases will not be considered in detail. It is of interest to note that in 3 cases of lymphosarcoma the disease was primary in bone and showed little or no extension to other organs. These may be examples of the primary reticulum cell sarcoma of bone recently described by Parker and Jackson (15) which these authors believe to be a separate entity. All of these patients had serum phosphatase values well within normal limits, resembling in this respect cases of plasma cell myeloma among the primary bone tumors. The 3 cases are from the clinic of Dr. B. L. Coley of the Bone Service of this hospital.

In 3 cases in the miscellaneous group the presenting symptom was polycythemia. This was fairly well controlled at the time of first phosphatase determinations, but a leukemic tendency had also appeared. Adenopathy was slight or absent but splenomegaly was present. All these patients complained of pain and tenderness in the bones but roentgenograms failed to show any definite abnormalities except one small osteolytic lesion of the tibia in 1 case. In all cases the serum phosphatase was moderately elevated to from 6.2 to 9.0 units. This is interesting in view of the recent work of Sabin and coworkers (16) who have shown that, in rabbits which are anemic and leukopenic at birth, the demands on the bone marrow in early extrauterine life cause a proliferation of osteoclasts and enlargement of the marrow cavity. The similar proliferation of osteoclasts which occurs in hyperparathyroidism is known to be associated with an elevation of serum phosphatase. If the hyperplastic marrow of polycythemia also tends to stimulate the mechanism for enlargement of the marrow cavity at the expense of the adjacent bone, then an increase in serum phosphatase is to be expected.

\section{COMMENT}

The evidence obtained in this investigation lends support to the belief previously expressed by one of us (17) that bone involvement is much more common in the lymphomatoid diseases than the incidence of overt lesions would indicate. However, the process appears to differ radically from that which takes place when the bones are the site of carcinoma metastases. Here the metastases, if untreated, progress regularly to a fatal termination, and the serum phosphatase, though higher in osteoplastic than in osteolytic disease, rises steadily with the spread of the metastases. In Hodgkin's disease, on the other hand, the progress of the bone lesions appears to be subject to relapses and remissions similar to those observed in other affected organs. As we have seen, the serum phosphatase of several of our cases showed over periods of many months somewhat elevated and fluctuating values associated with symptoms referable to the bones but unrelated to changes in adenopathy. Some of these patients eventually developed demonstrable bone changes, while others have not done so to date. If elevations of serum phosphatase indicate the presence of bone disease, as we believe they do, then these patients had bone pathology which made little progress over long periods. An important type of case is one in which the patient is obviously doing badly, yet has little adenopathy accessible to examination. When serum phosphatase readings remain persistently elevated in such patients, it seems likely that the disease is present principally in or about the bones. Finally, we have on several occasions observed a terminal rise of serum phosphatase to very high values. In these cases the disease had affected nearly every organ of the body, and had undoubtedly included the bones also.

As mentioned previously, the lymphosarcoma and leukemias present many unexplained anomalies, and further work will be necessary before the significance of serum phosphatase in these conditions can be made clear.

We may suggest a tentative explanation for the wide variations observed in the extent of serum phosphatase elevation between different cases of the same type. We believe that the elevation in phosphatase reflects a defense reaction on the part of the bones against invasion. If the defense is less than the invasive process, an osteolytic lesion will result. If the defense is greater than the invasive process, an osteoplastic lesion will result. If the two are equal, no demonstrable bone defect may develop, although symptoms may be present. Either or both may be slight or intense, but the degree of the serum 
phosphatase elevation will be a measure of the defense mechanism only.

\section{SUMMARY}

Serum phosphatase studies have been made on 115 patients with lymphomatoid disease, including 53 cases of Hodgkin's disease, 28 of lymphosarcoma, 26 of leukemia, and 8 of miscellaneous lymphomatoid disorders.

The alkaline serum phosphatase was frequently elevated in Hodgkin's disease, but less often in lymphosarcoma and the leukemias. Abnormalities in the acid serum phosphatase were not found.

Elevated serum phosphatase values occurred in many patients having symptoms referable to the bones, although no bone changes were demonstrable roentgenographically. Some of these patients later developed demonstrable lesions.

Bone changes probably occur much more frequently than the incidence of overt lesions indicates.

A persistently elevated serum phosphatase in a case of Hodgkin's disease probably indicates invasion of bone.

\section{BIBLIOGRAPHY}

1. Yamane, T., The phosphatase and pyrophosphatase of bones and cartilage. Arb. Anat. Inst. Kaiserlichen Univ. Kyoto, 1931, 3 Abt. Ser. C, No. 2, p. 49.

2. King, E. J., and Armstrong, A. P., A convenient method for determining serum and bile phosphatase activity. Canad. M. A. J., 1934, 31, 376.

3. Roche, J., Importance du substrat pour le $\mathrm{pH}$ optimum d'action des phosphatases sanguines (globules blancs et rouges, sérum). Compt rend. Soc. de biol., 1931, 107, 640.

4. Bauman, E., and Riedel, E., Uber das Vorkommen zweier durch das $\mathrm{pH}$ Wirkungsoptimum unterscheidbaren Phosphoesterasen in tierschen Organen. Ztschr. f. physiol. Chem., 1934, 229, 125.
5. Gutman, A. B., and Gutman, E. B., "Acid" phosphatase and functional activity of the prostate (man) and preputial glands (rat). Proc. Soc. Exper. Biol. and Med., 1938, 39, 529.

6. Roche, J., and Latreille, M., Sur les phosphatases du sang et de l'hémolymphe. Compt rend. Soc. de biol., 1934, 116, 1033.

7. Tweedy, W. R., and McNamara, E. W., Effect of administration of parathyroid extract on serum calcium level in the nephrectomized rat. Proc. Soc. Exper. Biol. and Med., 1936, 35, 414.

8. Franseen, C. C., and McLean, R., The phosphatase activity of tissues and plasma in tumors of bone. Am. J. Cancer, 1935, 24, 299.

9. Woodard, H. Q., and Higinbotham, N. L., The correlation between serum phosphatase and roentgenographic type in bone disease. Am. J. Cancer, 1937, 31, 221.

10. WoODARD, H. Q., A modification of the Bodansky method for the determination of inorganic phosphate. J. Lab. and Clin. Med., 1937, 22, 1287.

11. Barringer, B. S., and Woodard, H. Q., Prostatic carcinoma with extensive intraprostatic calcification, with a discussion of the possible rôle of prostatic phosphatase. Tr. Am. A. Genito-urin. Surgeons, 1939, 31, 363.

12. Bodansky, A., and Jaffe, H. L., Phosphatase studies. III. Serum phosphatase in diseases of the bone; interpretation and significance. Arch. Int. Med., 1934, 54, 88.

13. Freeman, S., Chen, Y. P., and Ivy, A. C., On the cause of the elevation of serum phosphatase in jaundice. J. Biol. Chem., 1938, 124, 79.

14. Woodard, H. Q., Twombly, G. H., and Coley, B. L., A study of the serum phosphatase in bone disease. J. Clin. Invest., 1936, 15, 193.

15. Parker, F., Jr., and Jackson, H., Jr., Primary reticulum cell sarcoma of bone. Surg., Gynec. and Obst., 1939, 68, 45.

16. Sabin, F. R., Miller, F. R., Smithburn, K. C., Thomas, R. M., and Hummel, L. E., Changes in the bone marrow and blood cells of developing rabbits. J. Exper. Med., 1936, 64, 97.

17. Craver, L. F., The treatment of the more important lymphadenopathies, with special reference to irradiation. Medical Clinics of North America, 1934, p. 703. 